\title{
Impact of automated guidance for mechanical control of herbicide- resistant weeds in corn
}

\author{
by Griffin, T. and Lowenberg-DeBoer, J.
}

Copyright, Publisher and Additional Information: Publishers version distributed under the terms of the CC-BY-NC-ND

https://creativecommons.org/licenses/by-nc-nd/4.0/legalcode

Link to publisher's site: https://docs.lib.purdue.edu/jafe/vol1/iss2/5/

\section{Harper Adams} University 


\section{Journal of Applied Farm Economics}

Volume 1 | Issue 2

Article 5

2017

\section{Impact of Automated Guidance for Mechanical Control of Herbicide-Resistant Weeds in Corn}

Terry Griffin

Kansas State University, spaceplowboy@gmail.com

James M. Lowenberg-DeBoer

Purdue University, lowenbej@purdue.edu

Follow this and additional works at: http:// docs.lib.purdue.edu/jafe

Part of the Agribusiness Commons, Agricultural Economics Commons, Agronomy and Crop Sciences Commons, and the Weed Science Commons

\section{Recommended Citation}

Griffin, Terry and Lowenberg-DeBoer, James M. (2017) "Impact of Automated Guidance for Mechanical Control of HerbicideResistant Weeds in Corn," Journal of Applied Farm Economics: Vol. 1 : Iss. 2 , Article 5.

Available at: http://docs.lib.purdue.edu/jafe/vol1/iss2/5

This document has been made available through Purdue e-Pubs, a service of the Purdue University Libraries. Please contact epubs@purdue.edu for additional information.

This is an Open Access journal. This means that it uses a funding model that does not charge readers or their institutions for access. Readers may freely read, download, copy, distribute, print, search, or link to the full texts of articles. This journal is covered under the CC BY-NC-ND license. 


\section{Impact of Automated Guidance for Mechanical Control of Herbicide- Resistant Weeds in Corn}

\section{Cover Page Footnote}

The authors appreciate continued support of the Purdue linear programming model for research, teaching, and Extension. 


\title{
Impact of Automated Guidance for Mechanical Control of Herbicide-Resistant Weeds in Corn
}

\author{
Terry Griffin (Kansas State University), and J. Lowenberg-DeBoer (Purdue University)
}

\begin{abstract}
This study evaluated the feasibility of reintroducing mechanical weed control as an alternative for herbicide-resistance weed infestations. The production practice tested included row cultivation with a separate banded spray application using high-accuracy automated guidance systems. A range of ground speeds were tested for the row cultivation operation, each with a different per acre cost and timeliness penalty. A typical eastern Corn Belt farm with a rotation of corn and soybean served as the base for the linear programming model. It was found that if the farmer was willing to reintroduce tillage, row cultivation conducted at higher operating speeds in conjunction with separate banded application could be justified under a range of relatively inexpensive herbicide costs as low as $\$ 7$ per acre. When effective herbicides were relatively expensive at $\$ 30$ per acre, the optimal decision would be to use row cultivation and reduce herbicides via banding. At faster ground speeds, the majority of hours devoted to row cultivation shifted to earlier time periods so that yield penalties were avoided.
\end{abstract}

\section{KEY WORDS}

linear programming, precision agriculture, herbicide resistance, whole-farm
Precision agriculture is a form of information technology applied to agriculture. Most precision agriculture applications can be assigned to one of two categories. The first is "information intensive," using soil mapping, variable rate application, yield monitors, and other sensors that provide spatial information that must be analyzed before it is useful for decision making (Fernandez-Cornejo et al., 2001). The second group is "embodied-knowledge" technologies, requiring less skill and management ability than without the technology (Fernandez-Cornejo et al., 2001). Global navigation satellite system (GNSS, formerly known as the global positioning system, or GPS) technologies such as automated guidance systems are in the second group. Technologies from the latter group have been adopted at higher rates by farmers and practitioners than technologies from the former (Erickson \& Widmar, 2015; Griffin et al., 2017; Schimmelpfennig \& Ebel, 2011) because embodied-knowledge technology reduces human capital requirements relative to the status quo (Fernandez-Cornejo et al., 2001; Griffin et al., 2004).
GNSS-enabled navigation technologies are increasingly being used by commercial applicators and farmers. Service providers have rapidly adopted automated guidance since commercialization in the early 2000s, with current adoption rates over $80 \%$ (Erickson \& Widmar, 2015). Farmlevel trends have been similar to service providers; automated guidance was reported to be used on $45 \%$ to $55 \%$ of planted acres from 2010 to 2013 (Schimmelpfennig, 2016) and 67\% of Kansas farms in 2015 (Griffin et al., 2017). GNSS-enabled automated guidance controls the steering of the equipment in parallel or contour swaths (Grisso et al., 2009).

Automated guidance systems potentially increase field efficiency. Griffin et al. (2005) described some of the GNSS guidance benefits claimed by industry, including (1) a reduction in equipment overlap, (2) increased field operation ground speeds, (3) an increase in the number of labor hours per day while reducing fatigue, and (4) more appropriate placement of inputs including fall applied nitrogen, row cultivation, and controlled trafficking of tracks and wheels. These 
advantages allowed more timely field operations that potentially led to improved yields and reduced machinery constraints for a given equipment set. Recent advancements to sprayer technology such as automated boom height control (Sharda et al., 2016) also provide the potential to make banded herbicide applications.

The use of herbicide weed control has been an integral part of farm management for several decades due to being an efficient and cost-effective alternative to mechanical weed control management. However, repeated use of broad spectrum herbicides has resulted in herbicide resistance in several weed species (Norsworthy et al., 2012). Although the indiscriminate use of herbicides has been linked to the quick and widespread adoption of herbicide-resistant crop species (FernandezCornejo et al., 2014), research indicates that herbicide resistance predates the introduction of biotech crops by several decades (Weed Science Society of America, 2016). By the time the U.S. Department of Agriculture (USDA) began tracking the adoption of biotech soybean production in 2000, over half of U.S. acreage was planted to herbicide-tolerant varieties and reached over $90 \%$ within seven years (USDA National Agricultural Statistics Service) (Figure 1). By 2013, 90\% of corn and soybean acreage was planted to biotech cultivars including herbicide-tolerant only and stacked genes (see Figure 1). Currently, 485 unique cases of herbicide resistance have been documented (Heap, 2017). Multiple herbicide-resistant weed species cause additional concern due to reduced herbicide options and increased weed control costs. Multiple herbicide resistance has been confirmed in economically important weeds including Palmer amaranth (Amaranthus palmeri) (Nandula et al., 2012), waterhemp (Amaranthus tuberculatus Sauer) (Bell et al., 2013), horseweed (Conyza canadensis L. Cronq.) (Davis et al., 2009), rigid ryegrass (Lolium rigidum Gaudim) (Owen et al., 2014), and kochia (Kochia scoparia [L.] Schrad.) (Foes et al., 1999) (for more details on herbicide resistance weeds, see Heap, 2017). Recently, biotech soybean varieties tolerant to dicamba have been the focus of substantial controversy due to potential drift on nontolerant soybean fields.

The objective of this study was to determine how GNSS-enabled automated guidance may impact farmers' options for controlling herbicide-resistant

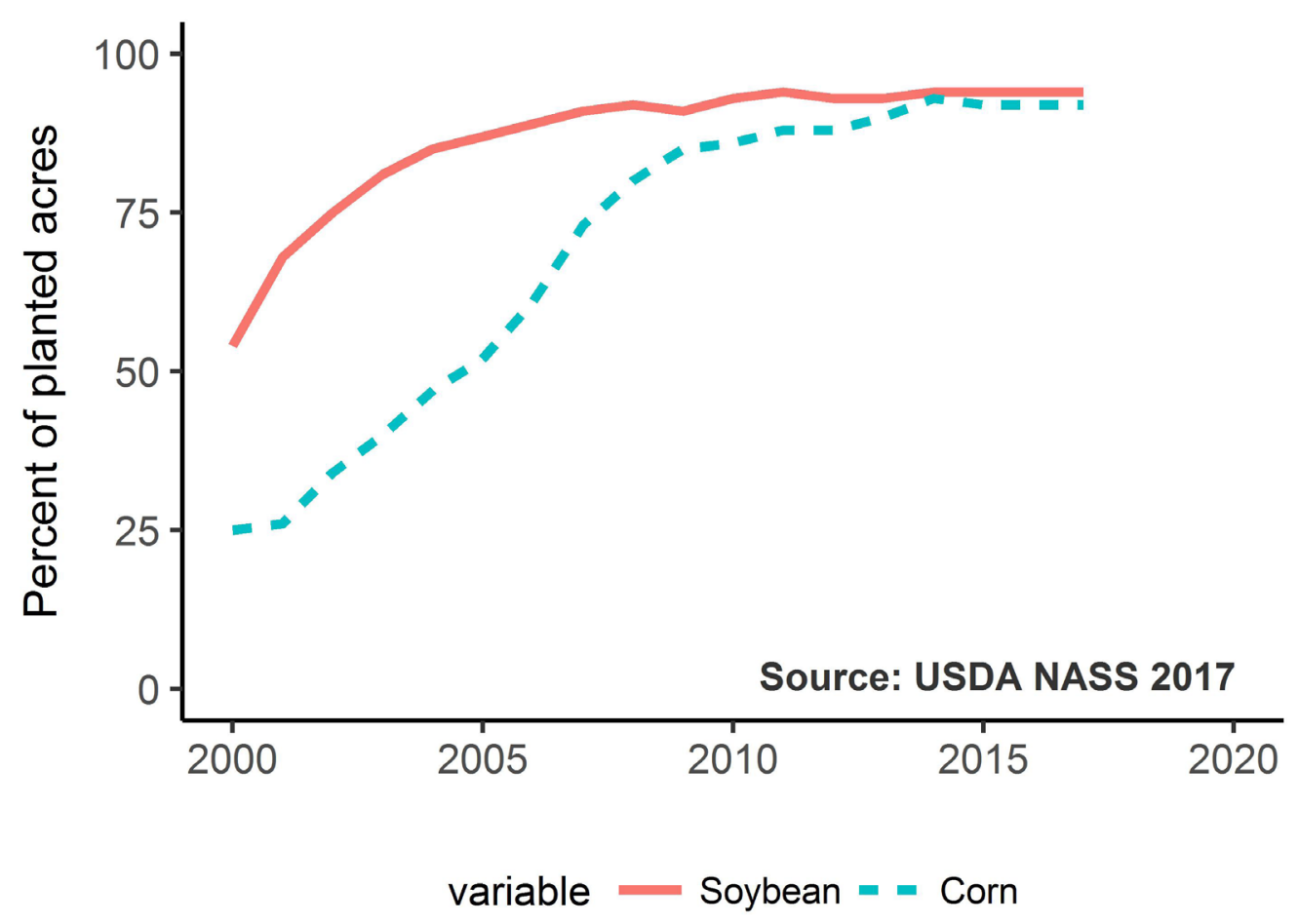

Figure 1. Adoption of herbicide-tolerant genetically modified crops in the United States, 2000-2017. Source: USDA NASS June Agricultural Acreage Survey 
weed escapes. Specifically, the use of mechanical weed control mated with separate banded herbicide application was evaluated under a range of conditions to determine at what prices farmers would consider alternative weed control methods. Using mathematical programming techniques, this study was first to report how high-accuracy GNSS could be useful in controlling resistant weed species by integrating mechanical and chemical weed control practices.

\section{LITERATURE REVIEW}

The economic feasibility of GNSS-enabled guidance systems was analyzed soon after the technologies were introduced (Griffin et al., 2005; Medlin \& Lowenberg-Deboer, 2000; Watson \& Lowenberg-DeBoer, 2004). Watson and Lowenberg-DeBoer (2004) used deterministic spreadsheet calculations to ascertain how increasing working rates and the workday affected farm size potential by adding the guidance system to an existing farm. Griffin et al. (2005) expanded upon Watson and Lowenberg-DeBoer (2004) by formulating similar scenarios in a whole-farm mathematical programming model. Watson and Lowenberg-DeBoer (2004) examined soil compaction and controlled trafficking, making stochastic estimations of yield penalties associated with wheel traffic. Shockley et al. (2011) built upon their mathematical programming methodology by evaluating changes in production practices and risk aversion preferences.

GNSS-enabled navigation technologies have been tested in weed control systems. Carballido et al. (2013) reported field trials using GNSS to apply banded selective herbicides with nonselective herbicides. Blake (2013) reported the use of automated guidance for both mechanical and chemical weed control practices in Arizona. Slaughter et al. (2012) and Carballido et al. (2013) reported labor savings from weed control systems utilizing precision agricultural technology. Swinton (2005) provided an overview of an ecological weed management approach where site-specific tools were mated to the decision support system.

Chemical weed control has been combined with mechanical weed control practices for a variety of agricultural systems. Bates et al. (2012) conducted field experiments to evaluate the economics of integrating mechanical weed control into existing systems and reported reduced herbicide applications by as much as $70 \%$ without loss of yield. Mechanical weed control practices have been evaluated in conservation tillage corn production systems (Bates et al., 2012, Buhler et al., 1995; Teasdale, 1993). These studies suggest that mechanical weed control practices may have a role in chemical weed control systems, in particular by controlling herbicide-resistant weeds (Boerboom, 1999). Mechanical weed control is almost essential in organic production systems (Diekmann \& Batte, 2014) to replace the utilization of synthetic pesticides (Rasmussen, 2004).

Although mechanical weed control has declined in the Corn Belt due to time constraints and reduction in tillage operations by some farmers, it remains a viable alternative for herbicide resistance (Boerboom, 1999) and organic production (Diekmann \& Batte, 2014). Given the prevalence of herbicideresistant weed species (Heap, 2017) and evidence that a single herbicide-resistant weed escape can overtake an entire field in less than three years (Norsworthy et al., 2014), automated guidance systems may be the embodied knowledge technology that enables farmers to integrate mechanical weed control with chemical weed control.

\section{MATERIALS AND METHODS}

This analysis builds on earlier studies by evaluating the potential of automated guidance to integrate mechanical weed control with banded herbicide application. In this study, the hypothetical farm decision maker had a herbicide-resistant weed population that is not sufficiently controlled by the status quo chemical weed control practices. The farmer is considering row cultivation combined with banded herbicide application rather than a broadcast application of a relatively expensive herbicide to control weeds. A row, or sweep, cultivator is a tillage toolbar implement that stirs the soil a few inches deep, physically removing weeds between crop rows. The sweep is the blade that comes into contact with the soil surface. With increased accuracy, the probability of crop damage from mechanical weed control is minimized even at faster ground speeds (i.e., higher working rates) until crop growth reaches canopy closure. Broadcast applications of relatively expensive 
herbicides are replaced with mechanical weed control and separate banded postemerge herbicide application of the expensive herbicide, allowing for reduced herbicide use and cost while still controlling weeds.

This analysis built upon the linear programming (LP) models presented by Griffin et al. (2005, 2014) and Rosburg (2017) to examine the utilization of a high-accuracy automated guidance system for separate row cultivation and banded herbicide application. Row cultivator sweeps and herbicide bands come in a variety of sizes. Band widths were assumed to be at least as wide as the difference between the 30-inch row width and the width of sweeps within the row.

Once the base farm was defined, it was modified in a series of LP runs using Purdue Crop/ Livestock Linear Programming (PCLP) software (see Dobbins et al., 2001, for the user's manual and Preckel et al., 1992, for details on model formulation). Variations of the model have been used for over four decades. It was chosen to conduct this research because thousands of farmers (more than 7,000 farmers as of 2004 according to Griffin et al., 2005) have relied on, trusted, and input their own information over 25,000 times, validating the model (Candler et al., 1970; McCarl et al., 1977). LP is a mathematical tool for solving an objective function such as maximizing returns to fixed costs with respect to a set of whole-farm constraints on land, unpaid family labor, and capital under a given weather regime (Dantzig, 1949, 1963). For the nonmathematical, LP is best understood as automated budgeting. It facilitates budget comparisons for thousands of alternatives and identification of the highest return alternative. The optimization problem was specified as an LP model in the standard summation notation as written in Boehlje and Eidman (1982, pp. 404-405) as:

$$
\operatorname{Max} \Pi=\sum_{j=1}^{n} c_{j} X_{j}
$$

subject to:

$$
\begin{gathered}
\sum_{j=1}^{n} a_{i j} X_{j} \leq b_{j} \text { for } i=1 \ldots m \\
X_{j} \geq 0 \text { for } j=1 \ldots n
\end{gathered}
$$

where:

$\mathrm{X}_{\mathrm{i}}=$ the level of the $\mathrm{j}^{\text {th }}$ production process or activity,

$c_{j}=$ the per unit return to the unpaid resources (b.s) for the $\mathrm{j}^{\mathrm{t} \text { th }}$ activity,

$a_{i j}=$ the amount of the $i^{\text {th }}$ resource required per

unit of the $\mathrm{j}^{\text {th }}$ activity, and

$b_{i}=$ the amount of the $i^{\text {th }}$ resource available.

The objective function (Equation 1) maximizes per unit net returns $\left(c_{i}\right)$ from all activities $\left(X_{i}\right)$. Equation 2 defines the constraints on how many units of each activity can be in the optimal solution. The $j$ activities include production of two crops, corn and soybean, grown in rotation. The $i$ resources include (1) land available for crop production; (2) available labor expressed as a combination of number of people, number of hours per day, and number of days suitable for fieldwork per period; and (3) the availability of machinery based on number of machines of each type, number of hours per day that the machine is available, and working rates expressed as acres per hour for each crop production task. The remaining variables $a$ and $b$ are the production process or activity resource requirements and resource availability constraints, respectively. In all, there were nearly 1,000 constraints. The production season was segmented into 20 time period constraints; the most active planting and harvesting times were in oneweek increments and longer periods otherwise. Labor constraints were divided into unpaid and hourly wage earners. Equation 3 prevents negative production.

Versions of the model have evaluated a variety of production issues in a series of studies. Most recently, Rosburg (2017) modified b to determine if an existing farm could support a beginning farmer by adding land but keeping machinery constant. Griffin et al. (2014) varied the number of good days to conduct fieldwork in $b_{i}$ to calculate the impacts from planting and harvest downtime framed as diverting farm equipment to implement on-farm experiments. Griffin et al. (2005) also modified $b_{i}$ to iterate over a range of working rates of specific field machinery to determine whole-farm impacts of adding higher-accuracy guidance systems to existing field equipment. Like Griffin et al. (2014), Nistor and Lowenberg-DeBoer (2007) changed the 
hours per day constraint, $b_{i}$, to model increased labor availability for controlled drainage. Robertson (2006) and Cain (2006) altered the $\mathrm{a}_{i j}$ matrix of cropping systems to evaluate the long-term profitability of continuous corn and alternative tillage methods, respectively. Additional details about the model input data and operating procedures can be found in Dobbins et al. (2001), Doster et al. (2010), and Preckel et al. (1992).

Contribution margin $(\pi)$, defined as total wholefarm returns to fixed costs, can be calculated as total crop sales revenue minus total direct costs and can be considered whole-farm profit. Fixed costs include land costs, equipment costs including automated guidance system associated costs, and returns to management and unpaid labor. In this analysis, the objective function of the LP model was to maximize contribution margin or profit. Partial budget analyses were conducted using the contribution margin values estimated from each run of the LP model. This analysis reported the scenario where mechanical weed control was added to an existing farm with automated guidance. Since all alternatives include the same sprayer and broadcast herbicide application, these fixed costs were omitted from the partial budget, but per acre costs of operations and additional herbicides were accounted for when additional spray operations were conducted.

Four assumptions guide this analysis. First, for control of resistant weeds, effective herbicides are relatively more expensive than ineffective herbicides. Second, weed distributions are relatively uniform, not clustered patches, such that spot spraying was not a viable option. Third, mechanical weed control is a perfect substitute for broadcast herbicide application in the row middles (i.e., the former is at least as effective in weed control efficacy and as equivalent with respect to yield penalties). Fourth, any GNSS accuracy is sufficient for broadcast herbicide application; however, only high-accuracy GNSS is adequate to make banded spray applications with the 90 -foot boom sprayer.

\section{DEFINING THE BASE SCENARIO AND PARAMETERIZING THE LP MODEL}

The base farm was defined as a representativesize single equipment set U.S. Corn Belt farm. The weather parameters were set specifically to Indiana in the eastern portion of the Corn Belt. A single equipment set farm is sized such that one planter, one grain drill, and one harvester are sufficient to cover all the acreage in a typical year. The 3,000-acre hypothetical farm has three tractors; two each of the 24-foot chisel, 32-foot disk, and 42 -foot field cultivator; and one each of the 90foot boom self-propelled sprayer, 24-row planter, 30 -foot grain drill, combine ( $370 \mathrm{hp}$ ), 12-row corn head, and 30-foot soybean head (Table 1). A chisel is a primary tillage implement that minimizes soil inversion while preserving some crop residue on the surface. A field cultivator is a secondary tillage implement that incorporates crop residue into the soil. A disk is a primary tillage implement that incorporates crop residue while stirring the soil.

Table 1. Inventory of implements, size, field efficiency, and working rates without GNSS guidance

\begin{tabular}{lccccc}
\hline Implement & Number & $\begin{array}{c}\text { Width } \\
(\text { feet })\end{array}$ & $\begin{array}{c}\text { Field efficiency } \\
(\%)\end{array}$ & $\begin{array}{c}\text { Ground speed } \\
(\mathrm{mph})\end{array}$ & $\begin{array}{c}\text { Working rate } \\
\text { (acre per hr) }\end{array}$ \\
\hline Disc & 2 & 32 & 80 & 5.25 & 16.3 \\
Chisel plow & 2 & 24 & 85 & 5.25 & 13.1 \\
Field cultivator & 2 & 42 & 85 & 6.50 & 28.2 \\
Boom sprayer & 1 & 90 & 65 & 12.7 & 90.0 \\
Planter (corn) & 1 & 60 & 70 & 6.20 & 31.9 \\
Drill (soybean) & 1 & 30 & 70 & 6.25 & 15.8 \\
Harvester (corn) & 1 & 30 & 85 & 3.85 & 11.9 \\
Harvester (soybean) & 1 & 30 & 85 & 3.85 & 11.9 \\
Row cultivator & 1 & 20 & 80 & 5.00 & 9.7 \\
\hline
\end{tabular}

Source: Mississippi State Budget Generator (Laughlin \& Spurlock, 2008). 
Field operations were based on conventional tillage production systems reported in Cain (2006). The conventional tillage practice was to disk, chisel plow, and field cultivate prior to planting corn and then disk followed by field cultivation prior to planting soybean. Without automated guidance, tractors and implements could be used 12 hours per day and increased to 15 hours per day when automated guidance was utilized. Although planter overlap and speed were not impacted by automated guidance, GNSS-enabled guidance allowed the planter to be used for additional hours per day based on desire for straight and parallel rows. The combine was used 12 hours per day in corn and 8.5 hours per day in soybean. Except for the row cultivator, the number of acres covered per hour for each field operation held constant regardless of guidance technology. The number of acres worked per hour, or working rate, takes into account speed, size, and field efficiency of the machinery (see Table $1)$. For instance, the working rate for the corn planter was 31.9 acres per hour (see Table 1 ).

Weather probabilities were adjusted to ensure that model calculations were representative in a majority of years by setting the model to the 80th and 60th percentile worst years in the spring and fall, respectively, for the number of days that equipment can enter the field to conduct fieldwork. Doster et al. (2010) suggested setting spring (planting) and fall (harvesting) percentiles to the 75th-85th and 55th-60th worst years in 100, respectively, because yield penalties for late planting or harvest are severe in the eastern Corn Belt. The days worked per week were limited to 6.5.

The long-run nonstochastic prices were estimated from prices received by farmers (USDA National Agricultural Statistics Service, 2017). Expected yields and variable costs were chosen from the 2016 Purdue Crop Cost and Return Guide (Dobbins et al., 2015) for high-productivity soil. Full-season yields of 198 bushels per acre for corn and 60 bushels per acre for soybean and prices of $\$ 4.60$ per bushel for corn and $\$ 10.80$ per bushel for soybean were assigned to the model (Table 2). These yields assume good weed control. Variable costs of production were $\$ 449$ per acre for corn and $\$ 227$ for soybean.

Selective herbicides could be applied in bands over the row after planting in a separate row cultivation field operation using a real-time kinematic (RTK) automated guidance system $(+/-1 \mathrm{~cm})$. RTK offers the benefit of both relative and absolute accuracy (Buick, 2002). Relative or pass-topass accuracy is useful for swathing (i.e., returning to a parallel pass a few minutes after the previous pass) and was useful for field cultivation and spraying if previous or subsequent input applications were not being considered (Buick, 2002). Absolute accuracy is important for returning to the same location after extended periods of time, that is, planting in the appropriate location after fall fertilizer application, using controlled trafficking, or row cultivating growing crops at high speeds several weeks after planting (Buick, 2002).

Using an RTK-automated guidance system onetime cost of $\$ 8,000$, a useful life of 10 years with no salvage value, and a $7 \%$ discount rate, the annualized cost of automated guidance system was $\$ 1,360$. The useful life of guidance systems has not explicitly been estimated, although 5 years (Groover \& Grisso, 2009) to 12 years (Office of Financial Management, 2014) have been suggested; therefore, the 10-year useful life was chosen based on the useful life of the GNSS-enabled equipment. Automated guidance system costs include both the RTK and the automated guidance components on the tractor and sprayer.

Per acre costs of operation for the row cultivator were calculated for all five ground speeds (Table $3)$. For each speed, the field efficiency was held

Table 2. Crop yield, price, and production costs

\begin{tabular}{lccc}
\hline & $\begin{array}{c}\text { Crop yield* } \\
\text { (bu per acre) }\end{array}$ & $\begin{array}{c}\text { Crop price** } \\
\text { (per bushel) }\end{array}$ & $\begin{array}{c}\text { Variable costs* } \\
\text { (per acre) }\end{array}$ \\
\hline Corn & 198 & $\$ 4.60$ & $\$ 449$ \\
Soybean & 60 & $\$ 10.80$ & $\$ 227$ \\
\hline "Dobbins et al. 2015. & & \\
$*$ * USDA National Agricultural Statistics Service, 2017. &
\end{tabular}


Table 3. Row cultivator ground speed and working rate

\begin{tabular}{lccc}
\hline Scenario & $\begin{array}{c}\text { Ground speed } \\
\text { (miles per hour) }\end{array}$ & $\begin{array}{c}\text { Working rate* } \\
\text { (acres per hour) }\end{array}$ & $\begin{array}{c}\text { Total cost** } \\
\text { (\$ per acre) }\end{array}$ \\
\hline $1 \& 2$ & 5.0 & 9.7 & 9.99 \\
3 & 6.0 & 11.6 & 8.32 \\
4 & 7.0 & 13.6 & 7.14 \\
5 & 8.0 & 15.5 & 6.24 \\
6 & 9.0 & 17.5 & 5.55 \\
\hline
\end{tabular}

* Working rate calculations assumed a constant $80 \%$ field efficiency.

* Total cost of operation for fully utilized row cultivator including tractor costs. **Fully utilized row cultivator had an annual use of 150 hours per year.

* Assumed labor expense of $\$ 11$ per hour and fuel price of $\$ 3$ per gallon.

constant at $80 \%$ to avoid indirect impacts from differing field shapes and sizes. Hourly wages and per gallon fuel prices were assumed to be $\$ 11.00$ and $\$ 3.00$, respectively. The costs were calculated assuming full utilization at 150 hours per year. Per acre costs of row cultivator operation ranged from $\$ 9.99$ for 5 miles per hour to $\$ 5.55$ for 9 miles per hour (see Table 3).

Once the base farm was parameterized, the six LP model scenarios were run and output was collected. The first scenario (Scenario 1) added the row cultivator to the existing chemical weed control system but only for the corn acreage. Soybean acreage did not receive the row cultivator operation in any scenario. This hypothetical herbicideresistant weed scenario was more of a problem in corn than soybeans assuming that selective herbicides for soybeans could control the weed that was resistant to herbicides used in corn. In addition, mechanical weed control for soybeans would require substantial changes in production practices such as widening row widths from narrow rows (7 to 15 inches) to wider 30 -inch rows that may induce yield penalties. Row cultivation may complicate the harvest of soybeans by heaping soil up near base of plants. The LP model was updated by (1) adding the row cultivator operation to the list of activities, (2) requiring the operation to begin 4 weeks after planting and be completed within 1 week, and ( 3 ) adding the per acre cost of operation (see Table 3) to the variable costs. Scenario 2 built on Scenario 1 by adding automated guidance such that equipment constraints were extended and the annualized cost was subtracted from the contribution margin. Each subsequent run of the LP model
(Scenarios 3 to 6) increased the working rate of the row cultivator (see Table 3 for working rates and costs for each ground speed). Working rates were increased for the row cultivator operations to reflect relying on automated guidance instead of human control for accurate field operations. With no automated guidance on the row cultivator (Scenario 1), the field operation was conducted at 5 miles per hour, or 9.7 acres per hour (see Table 3). Five ground speeds were evaluated by iterating between 5.0 and 9.0 miles per hour in increments of 1.0 mile per hour (see Table 3). Ground speeds equated to working rates ranging from 9.7 to 17.5 acres per hour (see Table 3).

\section{RESULTS AND DISCUSSION}

Given the static and deterministic nature of the LP model, contribution margins were affected by the timeliness of the row cultivator operation based on the requirement to complete the operation within 1 week. Negative effects such as yield losses and weed escapes contributing to the soil weed seed bank occur if weed control is not conducted in a timely manner. To determine if automated guidance would influence mechanical weed control decisions to manage herbicide-resistant weed escapes, the number of hours that the row cultivator was operated in each of the one-week time periods was examined and the number of binding time periods reported. At slower speeds without RTK automated guidance, the majority of row cultivator capacity hours occurred during May 24May 30 and May 31-June 6. However, at faster speeds greater than or equal to 6 miles per hour, 
no row cultivator operations were conducted May 31 through June 6 . When operated between 8 and 9 miles per hour, the number of row cultivator utilization hours went to zero during the May 31 to June 6 time period, as planter field operations were more timely. At 9 miles per hour, the cultivator was only used in the two weeks between May 18 and May 30. When the row cultivator was introduced to the farm without automated guidance, five time periods were utilized and four were binding (Scenario 1). When automated guidance was adopted and the row cultivator was operated at the same speed (Scenario 2), utilization was reduced to four periods and was binding in three. For ground speeds of 6,7 , and 8 miles per hour, the row cultivator was utilized in three time periods, while two were binding. At 9 miles per hour, the row cultivator was used in two time periods and was binding in only one. These results indicate that faster operating speeds have whole-farm benefits.

The base farm returns to fixed costs with no mechanical weed control equipment had a potential of $\$ 636,371$ prior to herbicide-resistant weed infestations. However, under scenarios of herbicide-resistant weed escapes, these returns were reduced substantially. When the row cultivator was added to the farm to physically control the intrarow portion of the weed escapes (Scenario 1), contribution margin decreased to $\$ 601,031$ due to reduction in timeliness and cost of the additional field operation. When GNSS automated guidance was introduced to the farm, therefore allowing banded herbicide applications (Scenario 2), the contribution margin was $\$ 608,464$ (Scenario 2), $\$ 7,433$ more than in Scenario 1 but still less than the base case.
Returns increased as ground speeds of the row cultivator operation increased. When the row cultivator speed increased from 5 miles per hour to 6 miles per hour, returns increased by $\$ 20,123$ to $\$ 616,248$. Similar but lower marginal increases were observed from speeding up the field operation from 6 to 7 miles per hour. Returns for Scenarios 4 through 6 increased to $\$ 621,779, \$ 626,555$, and $\$ 628,260$, respectively (Table 4$)$. Even at the fastest row cultivator operating speeds, contribution margin never reached the returns realized before weed resistance. Therefore, herbicide costs or yield reduction due to poor weed control must be costly enough to offset the separate row cultivator and banded spraying operation costs (i.e., changes to the contribution margin).

As the row cultivator speed increased, per acre differences from the base contribution margin decreased but never went to zero. When the row cultivator operation was introduced to the base farm, contribution margins decreased by $\$ 23.56$ per acre of corn (see Table 4). When automated guidance was adopted, the difference fell to $\$ 18.60$ even at the same ground speed of 5 miles per hour. At the fastest ground speed of 9 miles per hour, the difference was $\$ 5.41$ per corn acre (see Table 4). Differences in contribution margin per corn acreage were examined for break-even herbicide analysis.

Bands from 4 to 24 inches were evaluated. Since herbicides could be applied in narrow bands instead of the entire row width, relatively expensive herbicides could be applied such that the changes in contribution margin could equate to zero.

For Scenario 1, contribution margins were reduced by $\$ 23.56$ per corn acre when the row

Table 4. Returns of adding mechanical weed control under automated guidance system management

\begin{tabular}{lccc}
\hline Scenario & $\begin{array}{c}\text { Contribution margin } \\
(\$ \text { per farm })\end{array}$ & $\begin{array}{c}\text { Change from base } \\
(\$ \text { per farm })\end{array}$ & $\begin{array}{c}\text { Change from base } \\
\text { (\$ per corn acre) }\end{array}$ \\
\hline 1 & 601,031 & 35,340 & 23.56 \\
2 & 608,464 & 27,907 & 18.60 \\
3 & 616,248 & 20,123 & 13.42 \\
4 & 621,779 & 14,592 & 9.73 \\
5 & 626,555 & 9,816 & 6.54 \\
6 & 628,260 & 8,111 & 5.41 \\
\hline
\end{tabular}


Table 5. Breakeven herbicide costs by spray band width and technology.

\begin{tabular}{lcrrrrr}
\hline & Scenario 1 & Scenario 2 & Scenario 3 & Scenario 4 & Scenario 5 & Scenario 6 \\
\hline Band width (inches) & 23.56 & 18.60 & 13.42 & 9.73 & 6.54 & 5.41 \\
\hline 2 & 353.40 & 279.07 & 201.23 & 145.92 & 98.16 & 81.11 \\
4 & 176.70 & 139.54 & 100.62 & 72.96 & 49.08 & 40.56 \\
6 & 117.80 & 93.02 & 67.08 & 48.64 & 32.72 & 27.04 \\
8 & 88.35 & 69.77 & 50.31 & 36.48 & 24.54 & 20.28 \\
10 & 70.68 & 55.81 & 40.25 & 29.18 & 19.63 & 16.22 \\
12 & 58.90 & 46.51 & 33.54 & 24.32 & 16.36 & 13.52 \\
14 & 50.49 & 39.87 & 28.75 & 20.85 & 14.02 & 11.59 \\
16 & 44.18 & 34.88 & 25.15 & 18.24 & 12.27 & 10.14 \\
18 & 39.27 & 31.01 & 22.36 & 16.21 & 10.91 & 9.01 \\
20 & 35.34 & 27.91 & 20.12 & 14.59 & 9.82 & 8.11 \\
22 & 32.13 & 25.37 & 18.29 & 13.27 & 8.92 & 7.37 \\
24 & 29.45 & 23.26 & 16.77 & 12.16 & 8.18 & 6.76 \\
\hline
\end{tabular}

cultivator operation was introduced (see Table 4); therefore, if cultivation mated with banded herbicide application is a perfect substitute for broadcast chemical weed control, the per acre herbicide costs must be greater than or equal to $\$ 23.56$ to justify integration of separate mechanical and chemical weed control practices. When applied in 14-inch bands, per acre herbicide costs must be at least $\$ 50.49$ to break even (Table 5). At more narrow bands such as 6 inches, the per acre herbicide costs must be $\$ 117.80$ to equate to the $\$ 23.56$ per acre difference in contribution margin.

In Scenario 2, automated guidance was added to the farm previously represented by Scenario 1 . Automated guidance with the same ground speed lowered the target breakeven from \$23.56 to $\$ 18.60$ per acre (see Table 4), allowing herbicides to be less expensive than for Scenario 1 but still able to entice farmers to integrate row cultivator with separate banded herbicide applications. For the 6 -inch band, per acre herbicide costs must be more than $\$ 93.02$ to encourage banding after a row cultivator operation (see Table 5). As row cultivator speed increased, the breakeven herbicide costs decreased. At 6 miles per hour (i.e., Scenario 3), breakeven herbicide costs were $\$ 67.08$ per acre for a 6-inch band. Scenario 4, Scenario 5, and Scenario 6 had similar decreases in breakeven herbicide prices of $\$ 48.64, \$ 32.72$, and $\$ 27.04$, respectively (see Table 5). A range of band widths from 2 to 24 inches are presented for the six scenarios in Table 5.

As the row cultivator working rate increased, the potential of row cultivator followed by banded spraying increased. The mechanical weed control costs per acre decreased as ground speed increased; therefore, the herbicide cost thresholds decreased (see Table 5). As a result, when herbicides were relatively more expensive to control an outbreak of herbicide-resistant weeds, mechanical weed control became a feasible alternative as row cultivator working rates increased. If herbicide costs were any higher, mechanical weed control with banded herbicide applications would be the optimal decision.

To put these results into perspective, commonly used herbicide costs were compared to breakeven results. Using expected prices, the calculated threshold values were compared to expected herbicide prices to give a point of reference. When the relatively inexpensive herbicide glyphosate was at $\$ 12$ per gallon (Ferrell \& Sellers, 2017) and was applied at 3 pints per acre, it would cost $\$ 4.50$ per acre as a broadcast application. None of the scenarios reported in Table 5 would encourage banding of this herbicide. A relatively more expensive herbicide, linuron (brand name 
Lorox DF), applied at 1.5 pound per acre costs $\$ 22$ per pound (Ferrell \& Sellers, 2017), or \$33 per acre. At 22-inch, 18-inch, 14-inch, and 10inch bands, the decision maker would consider banding at herbicide prices similar to linuron at the faster row cultivator speeds for Scenarios 1, 2, 3 , and 4, respectively. For Scenario 5 and Scenario 6 , the decision maker would consider banding at 6-inch bands. However, these examples are for a single herbicide. In reality, resistant weeds and, more specifically, weeds with multiple resistance may require multiple applications of two or more herbicides, so the linuron-priced example may be considered conservative.

\section{CONCLUSIONS}

The combination of automated guidance technology, mechanical weed control, and banded herbicide application provides an alternative to broadcast herbicide application as the optimal farm management decision. The breakeven analysis included the total costs of adding the row cultivator to the farm. Only relatively expensive herbicides would encourage the adoption of mechanical weed control with banded herbicide application.

These results indicated that mechanical weed control with banding was a feasible option under a range of row cultivator ground speeds examined. The optimal decision was to row cultivate with banded herbicide application when the herbicide was priced higher than changes to contribution margin. At relatively expensive herbicide costs, the farm would adopt mechanical weed control to offset the use of chemical products.

There are limitations to this analysis, including that it considers only a corn soybean rotation in the eastern Corn Belt; results may be different with other crop rotations and in other geographies. The potential of government program subsidies for reduced pesticide application have not been considered in this analysis. Since row cultivation is a form of tillage, no-till production benefits including soil health may be negated under a mechanical weed control system. In addition, possible impediments to physical weed control adoption may result from USDA Natural Resources Conservation Service soil conservation programs that encourage reduced tillage.
Herbicide-resistant weed escapes and expensive new herbicides may not be necessary to induce farmers to reconsider row cultivation for weed control or to adopt an automated guidance system. It may be more likely that GNSS navigation technology techniques find use in organic or other identity-preserved production systems in conjunction with existing systems. Newer and more expensive herbicides would have an even greater impact on these results. Recent price reductions in GNSS navigation technologies have made mechanical weed control with banded spray application more attractive.

\section{ACKNOWLEDGMENTS}

The authors appreciate Jordan Shockley for informal review and comments on previous versions of this manuscript, Ignacio Ciampitti for corn physiological growth stage and production insights, and Ajay Sharda for his agricultural technology perspective. Anonymous reviewers and the editors provided invaluable advice on improving the manuscript, as did Shelley Lowenberg-DeBoer for editorial comments. The authors express appreciation to the Departments of Agricultural Economics at Purdue University and Kansas State University for continued support of the PCLP model and parameterization of LP for extension and research, respectively.

\section{LITERATURE CITED}

Bates, R. T., Gallagher, R. S., Curran, W. S., \& Harper, J. K. (2012). Integrating mechanical and reduced chemical weed control in conservation tillage corn. Agronomy Journal, 104(2): 507-571.

Bell, M. S., Hager, A. G., \& Tranel, P. J. (2013). Multiple resistance to herbicides from four site-of-action groups in waterhemp (Amaranthus tuberculatus). Weed Science, 61(3): 460-468.

Blake, C. (2008). Auto-guidance technology tested in mechanically-cultivated cotton: Goal is to improve weed control, reduce herbicide use and save money. 2008 Agricultural Experiment Station Research Report. The University of Arizona, College of Agriculture and Life Sciences.

Boehlje, M. D., \& Eidman, V. R. (1984). Farm management. New York: Wiley. 
Boerboom, C. M. (1999). Nonchemical options for delaying weed resistance to herbicides in Midwest cropping systems. Weed Technology, 13(3): 636-642.

Buhler, D. D., Doll, J. J., Proost, R. T., \& Visocky, M. R. (1995). Integrating mechanical weeding with reduced herbicide use in conservation tillage corn production systems. Agronomy Journal, 87: 507-512.

Buick, R. (2002). GPS guidance-Making an informed decision. In P. C. Robert et al. (Ed.), Proceedings of the 6th International Conference on Precision Agriculture and Other Precision Resources Management (pp. 2059-2084). Minneapolis, July 14-18, 2002.

Cain, Z. T. (2006). Examining the economic and environmental impact of land use changes in the Matson Ditch Watershed. MS thesis, Purdue University, West Lafayette.

Candler, W., Boehlje, M. D., \& Saathoff, R. (1970). Computer software for farm management extension. American Journal of Agricultural Economics, 52(1): 71-80.

Carballido, J., Rodríguez-Lizana, A., Agüera, J., \& Pérez-Ruiz, M. (2013). Field sprayer for inter- and intra-row weed control: Performance and labor savings. Spanish Journal of Agricultural Research, 11(3): 642-651.

Dantzig, G. B. (1949). Programming interdependent activities, II, mathematical model. Econometrica, 17: 200-211.

Dantzig, G. B. (1963). Linear programming and extensions. Princeton, NJ: Princeton University Press.

Davis, V. M., Kruger, G. R., Stachler, J. M., Loux, M. M., \& Johnson, W. G. (2009). Growth and seed production of horseweed (Conyza canadensis) populations resistant to glyphosate, ALS-inhibiting, and multiple (Glyphosate + ALS-inhibiting) herbicides. Weed Science, 57(5): 494-504. https://doi.org/10 .1614/WS-09-024.1

Diekmann, F., \& Batte, M. T. (2014). Economics of technology for precision weed control in conventional and organic systems. In S. L. Young and F. J. Pierce (Eds.). Automation: The future of weed control in cropping systems (pp. 203-220). Dordrecht, Netherlands: Springer Netherlands.

Dobbins, C. L., Langemeier, M. R., Nielsen, B., Vyn, T. J., Johnson, B., \& Wise, K. (2015). 2016 Purdue crop cost and return guide. ID-166-W. Purdue University. Available at https://ag.purdue.edu/commercialag /Documents/Resources/Mangagement-Strategy /Crop-Economics/Crop\%20Budget/2015_09_01 _Langemeier_Purdue_Crop_Budgets.pdf

Dobbins, C. L., Han, Y., Preckel, P., \& Doster, D. H. (2001). Purdue crop/livestock linear program user's manual. West Lafayette, IN: Purdue University.
Doster, D. H., Dobbins, C. L., Griffin, T. W., \& Erickson, B. (2010). B-21 input form guide book. C-EC11-Rev. Department of Agricultural Economics, Purdue University. Available at https://www.agecon .purdue.edu/topfarmer/documents/B21_InputGB .pdf

Erickson, B., \& Widmar, D. A. (2015). 2015 precision agricultural services dealership survey results. Purdue University. Available at http://agribusiness . purdue.edu/resources/2015-precision-dealership -survey-results

Fernandez-Cornejo, J., Daberkow, S., \& McBride, W. (2001). Decomposing the size effect on the adoption of innovations: Agrobiotechnology and precision agriculture. AgBioForum, 4(2): 124-236.

Fernandez-Cornejo, J., Wechsler, S., Livingston, M., \& Mitchell, L. (2014). Genetically engineered crops in the united states. United States Department of Agriculture Economic Research Service Economic Research Report ERR 162. Available at https:// www.ers.usda.gov/publications/pub-details/?pubid= 45182

Ferrell, J. A., \& Sellers, B. A. (2017). Approximate herbicide pricing. SS-AGR-16 University of Florida IFAS Extension. Available at http://edis.ifas.ufl.edu/wg056

Foes, M. J., Liu, L., Vigue, G., Stoller, E. W., Wax, L. M., \& Tranel, P. J. (1999). A Kochia (Kochia scoparia) biotype resistant to Triazine and ALS-inhibiting herbicides. Weed Science, 47(1): 20-27.

Griffin, T. W., Miller, N. J., Bergtold, J. Shanoyan, A. Sharda, A., \& Ciampitti, I. A. (2017). Farm's sequence of adoption of information-intensive precision agricultural technology. Applied Engineering in Agriculture, 33(4):521-527.

Griffin, T. W., Lowenberg-DeBoer, J., Lambert, D. M., Peone, J., Payne, T., \& Daberkow, S. G. (2004). Adoption, profitability, and making better use of precision farming data. Staff Paper \#04-06. Department of Agricultural Economics, Purdue University.

Griffin, T. W., Lambert, D. M., \& Lowenberg-DeBoer, J. (2005). Economics of lightbar and auto-guidance GPS navigation technologies. In John Stafford (Ed.), Precision agriculture '05 (pp. 581-587). Fifth European Conference on Precision. Agriculture, Uppsala, Sweden. Netherlands, Wageningen Academic Publishers.

Griffin, T. W., Mark, T. B., Dobbins, C. L., \& LowenbergDeBoer, J. M. (2014). Estimating whole farm costs of conducting on-farm research: A linear programming approach. International Journal of Agricultural Management, 4(1): 21-27. https://doi.org/10.5836 /ijam/2014-01-04

Grisso, R. D., Alley, M. M. \& Groover, G. E. (2009). Precision farming tools: GPS navigation. 
Virginia Cooperative Extension Publication 442-501. Available at https://vtechworks.lib.vt.edu/bitstream /handle/10919/51374/442-501.pdf? sequence $=1 \&$ is Allowed $=\mathrm{y}$.

Groover, G., \& Grisso, R. D. (2009). Investing in GPS guidance systems? Publication 448-076. Virginia Cooperative Extension. Available at https://pubs.ext .vt.edu/448/448-076/448-076_pdf.pdf

Heap, I. (2017). The international survey of herbicide resistant weeds. Available at www.weedscience.com

Laughlin, D. H., \& Spurlock, S. R. (2008). User's guide for the Mississippi State budget generator: Version 6.0 for Windows. Department of Agricultural Economics Mississippi State University. Available at http://www.agecon.msstate.edu/whatwedo/budgets /generator/docs/userguide6.pdf

McCarl, B. A., Candler, W. V., Doster, D. H., \& Robbins, P. R. (1977). Experiences with farmer oriented linear programming for crop planning. Canadian Journal of Agricultural Economics, 25: 17-30.

Medlin, C., \& Lowenberg-DeBoer, J. (2000). Increasing cost effectiveness of weed control. In Jess Lowenberg-DeBoer and Kathleen Erickson (Eds.), Precision farming profitability (pp. 44-55). West Lafayette, IN: Purdue Research Foundation.

Nandula, V. K., Reddy, K. N., Koger, C. H., Poston, D. H., Rimando, A. M., Kuke, S. O., Bond, J. A., \& Ribeiro, D. N. (2012). Multiple resistance to glyphosate and pyrithiobac in palmer amaranth (Amaranthus palmeri) from Mississippi and response to flumiclorac. Weed Science, 60(2): 179-188. https:// doi.org/10.1614/WS-D-11-00157.1

Nistor, A. P., \& Lowenberg-DeBoer, J. (2007). Drainage water management impact on farm profitability. Journal of Soil and Water Conservation, 62(6).

Norsworthy, J. K., Ward, S. M., Shaw, D. R., Llewellyn, R. S., Nichols, R. L., Webster, T. M., Bradley, K. W., Frisvold, G., Powles, S. B., Burgos, N. R., Witt, W. W., \& Barrett, M. (2012). Reducing the risks of herbicide resistance: Best management practices and recommendations. Weed Science, 60(sp 1): 31-62.

Norsworthy, J. K., Griffith, G., Griffin, T. W., Bagavathiannan, M., \& Gbur, E. E. (2014). In-field movement of glyphosate-resistant Palmer Amaranth (Amaranthus palmeri) and its impact on cotton lint yield: Evidence supporting a zero-threshold strategy. Weed Science, 62(2): 237-249.

Office of Financial Management. (2014). Capital Asset Class and Location Code Tables. State Administrative and Accounting Manual 30.50.10. Available at http://www.ofm.wa.gov/policy/30.50.pdf

Owen, M. J., Martinez, N. J., \& Powles, S. B. (2014). Multiple herbicide-resistant Lolium rigidum (annual ryegrass) now dominates across the western Australian grain belt. Weed Research, 54(3): 314-324 https:// doi.10.1111/wre.12068

Preckel, P., Han, Y., Dobbins, C. L., \& Doster, D. H. (1992). Purdue crop/livestock linear program formulation, PC-LP Version 2.0. Purdue Research Foundation, Purdue University.

Rasmussen, I. A. (2004). The effect of sowing date, stale seedbed, row width and mechanical weed control on weeds and yields of organic winter wheat. Weed Research, 44(1): 12-20.

Robertson, K. (2006). Exploring the profit potential of continuous corn using linear programming. MS thesis, Purdue University.

Rosburg, B. (2017). Inter-generational transition strategy assessment: The case of Rosburg farms. MS thesis, Kansas State University, Available at http:// krex.k-state.edu/dspace/handle/2097/35381

Schimmelpfennig, D., \& Ebel, R. (2011). On the doorstep of the information age: Recent adoption of precision agriculture. U.S. Department of Agriculture, EIB-80, Economic Research Service. Available at https://www.ers.usda.gov/publications/pub -details/?pubid=44576

Schimmelpfennig, D. (2016). Farm profits and adoption of precision agriculture. U.S. Department of Agriculture, Economic Research Service, Economic Research Report No. 217, 46 pp. Available at https://www.ers .usda.gov/publications/pub-details/?pubid $=80325$

Sharda, A., Griffin, T. W., Haag, L., \& Slocombe, J. W. (2016). Automatic boom height control technology for agricultural sprayers. Kansas State University Agricultural Experiment Station and Cooperative Extension Service, MF3299. Available at http:// www.bookstore.ksre.ksu.edu/pubs/MF3299.pdf

Shockley, J. M., Dillon, C. R., \& Stombaugh, T. S. (2011). A whole farm analysis of the influence of auto-steer navigation on net returns, risk, and production practices. Journal of Agricultural and Applied Economics, 43(1): 57-75.

Slaughter, D. C., Perez-Ruiz, M., Fathallah, F., Upadhayaya, S., Gliever, C. J., \& Miller, B. (2012). GPSbased intra-row weed control system: Performance and labor savings. Proceedings of the International Conference of Agricultural Engineering CIGRAgEng 2012. Valencia, Spain, July 8-12.

Swinton, S. (2005). Economics of site-specific weed management. Weed Science, 53: 259-263.

Teasdale, J. R. (1993). Reduced herbicide weed management systems for no-tillage corn (Zea mays L.) in a hairy vetch (Vicia villos) cover crop. Weed Technology, 7: 883-899.

USDA National Agricultural Statistics Service. (2017). June Agricultural Acreage Surveys, 2000 to 2017. National Agricultural Statistics Service (NASS), 
Agricultural Statistics Board, United States Department of Agriculture (USDA), June 30. Available at http://usda.mannlib.cornell.edu/usda/current/Acre /Acre-6-0-017.pdf

Watson, M., \& Lowenberg-DeBoer, J. (2004). Who will benefit from GPS auto guidance in the Corn Belt? Purdue Agricultural Economics Report. Available at http://www.agecon.purdue.edu/extension/pubs /paer/2004/paer0204.pdf
Weed Science Society of America. (2016). WSSA scientists say herbicide resistance predates genetically engineered crops by 40 years. Weed Science Society of America, Lawrence, Kansas, July 12. Available at http://wssa.net/2016/07/scientists-say-herbicide -resistance-predates-genetically-engineered-crops -by-40-years 